\title{
Sources for the Study of European Labor and Socialism (1840-1914) at Wisconsin
}

\section{History of THe Collection}

$I^{N}$ N THE LAST Two decades of the nineteenth century, the universities of the Midwest began to organize themselves for the advanced study of the social sciences. In 1892, as part of that development, there came to the University of Wisconsin a German-trained economist, author of a book on French and German socialism, Richard T. Ely. Because Ely was a man of considerable reputation, inducements were necessary to snare him, and among them was a special fund for books - the then "unheard" of sum of $\$ 5,000$. Another special fund of $\$ 2,500$ was made available to him about ten years later.

By the time of Ely's arrival, European labor unions had won the critical battle of legal existence; Marx had organized the "International"; and such leaders as Fourier, Owen, Proudhon, Lassalle, and Bebel had won a place in history. Much had been written by these leaders and their lesser colleagues, and some of it was already difficult to procure. Thus, though the funds placed at Ely's disposal may have seemed considerable at the time, there was not enough to make up for the lost opportunities of the past. Nevertheless, Ely succeeded in directing into the library a considerable body of source materials, including a fine collection of the writings of Robert Owen.

In 1904, John R. Commons arrived on the campus to begin his work on the his-

Dr. Kaplan is acting director, University of Wisconsin Libraries. tory of labor in America. While in the East, Commons had made the acquaintance of William English Walling. Walling, the son of a prominent and wealthy family, personable and widely acquainted, was a tireless worker in the socialist cause. A voluminous writer, he knew his way in the world of books. In 1907, as the result of his relationship with Commons, Walling presented Wisconsin with about 200 books, mainly on the subject of French and German socialism and labor.

In 1909, Walling sent Selig Perlman, a young student he had met in Italy, to study under Commons at Wisconsin. Later, when Perlman was to become a member of the faculty, the library collection was to benefit greatly from his wide knowledge of the European scene. At the moment, Perlman's contribution was to bind further the ties between Walling and Wisconsin. The stage now was set for a stroke of great good fortune. In New York, there came on the market the extensive collection gathered by Herman Schlueter, historian and editor of the socialist New Yorker Volkszeitung. Walling purchased the collection and gave the American portion to the State Historical Society and the European portion, consisting of no less than 600 titles, to the University.

The European portion of the Schlueter collection pertained mainly to Germany and to the First International. There was a wealth of material on the German Social Democratic Party, including minutes of meetings and election handbills and posters. On the revolution of 1848 
there was a considerable body of contemporary pamphlets, books, and periodicals. Also impressive were the periodicals of later years, particularly those published in the seventies and eighties, which, like those of the forties, are to be found in few American libraries. Of the books written by important socialist and labor leaders of Germany there was a gratifying array. A group of socialist song books was also in the collection. And as a dash of spice, there were the books of about seventy literary figures whose novels, essays, and poetry could be characterized as socially progressive. But one would search in vain for materials pertaining to individual labor unions, for seemingly Schlueter was interested only in books that dealt with theory and the problems of political organization.

By 1910, Ely's chief interest was no longer in socialism. But by virtue of the connection between Commons and the American Bureau of Industrial Research, gift materials continued to come to Madison, either to the library of the University or to that of the State Historical Society which in those days was responsible for both American and British materials. Among the noteworthy European sources that were acquired as the result of the activity of Commons and his associates were the publications of a considerable number of English labor unions.

In the twenties and thirties the University library suffered from insufficient funds. Thus, at a time when many older books of importance were coming on the market at prices that now seem fantastically low, there was no money to acquire them. Of the important books that were currently published, however, a goodly number were purchased. After 1945, when the library was favored with increased funds, the task of filling the gaps among the older books was resumed with vigor. The chief acquisition of this latest period was a special collection of Russian revolutionary publications.

\section{Analysis of the Collection}

\section{Theoretical Classics}

The important theorists are not great in number, but for a variety of reasons there are formidable problems in acquiring some of their books. A good example is the collected writings of Marx, of which there is probably not a complete set of the best edition in the United States, owing to the fact that this was published in Moscow. Another difficulty is that a majority of the theoretical classics were written prior to 1860 , some in small editions and some in other circumstances that usually result in a scarcity of copies. For example, Charles Hall's The Effects of Civilization is presumably no longer extant in the first edition of 1805 , and even an 1850 second edition copy is difficult to obtain, judging by Wisconsin's unsuccessful efforts to do so.

In the chief writings of the major and minor ranking theorists, Wisconsin's collection is nearly complete-a statement that could not be made were it not for the existence in several instances of modern reprints. Unfortunately, the French have shown less interest in reprinting these books than have the English and the Germans.

\section{Books by Labor Leaders}

Generally speaking, books written by labor leaders are easier to purchase than are those by the theorists, for the reasons that most were published more recently and in circumstances that insure survival. On the other hand, gaps are inevitable because the number that must be acquired is large. Thus, Wisconsin lacks such important items as the collected writings of Viktor Adler, leader of the Austrian Social Democratic Party, the memoirs of Stephen Born, early organizer of German labor, and two of the more important books by Cesar de Paepe, who helped found the labor party in Belgium.

While Wisconsin's collection is generally strong in the writings of labor leaders, 
the English, Germans, and French are best represented. An unusual item is the 1860 book on labor unions written by T. J. Dunning, declared by the Webbs to be the best exposition of trade unionism by a working man. Of the Germans, the library has exceptional strength in the writings of the two Liebknechts, and of Lassalle.

\section{Periodicals and Newspapers}

Complete sets of labor and socialist periodicals are infrequently found in American libraries. To illustrate the situation: of the fourteen best-known English periodicals launched prior to 1900 , complete sets were lacking in five, according to the Union List of Serials. Only Wisconsin had as many as four in a complete state.

Thus it follows that any library which claims to have a good collection must temper its enthusiasm. It is with this thought in mind that a few periodicals and newspapers are here mentioned with pride. The Commonweal, representing the group with which William Morris was associated, is seemingly found complete only at Wisconsin, as is true of Révolte, the anarchist publication with which Kropotkin was connected. Another rare periodical is the Sozialdemokrat, which was smuggled into Germany during the years when socialist activity was banned in that country. Of considerable interest is the Junge Generation, published in Switzerland in the early forties by working men who were disciples of Marx. Among the indispensable items are the Vorwärts and the Arbeiterzeitung, organs of the Social Democrats in Germany and Austria respectively. An unusual group of Russian revolutionary periodicals is discussed below in the section on the Russian revolutionary movement.

\section{Congresses of Labor Unions and Parties}

A prime source for the study of labor unions and parties is the record of the proceedings of their congresses. Wisconsin's files of the proceedings of English unions is extensive, though spotty. Naturally, the collection includes most of the reports of the Trades Union Congress. Likewise prized are the reports of the meetings of the Labour Party and of the Independent Labour Party. Unfortunately, those of the Social Democratic Federation are lacking.

Much less plentiful are the holdings of the reports of the French unions and parties, of which, owing to the French habit of permitting principles to fractionize their politics, there has been a bewildering array. Only a private collector, it seems, could have kept up adequately with the maze of publishing that resulted.

The German reports show the collecting genius of Herman Schleuter. To his basic files, a number have since been added. Not only does the library own a file of the reports of the Social Democratic Party, but there is on the shelves as well the reports of the earlier parties founded by Lassalle and Bebel. Almost complete is the set of the proceedings of Germany's "master" union, the Generalkommission der Gewerkschaften.

Two other noteworthy items are the proceedings of the Austrian Social Democratic Party and the proceedings of several meetings of the Russian Social Democratic Labor Party.

\section{The Russian Revolutionary Collection}

This collection consists of about 1,500 titles, among which there are 70 periodicals. About two-thirds of the material belongs to "underground" literature, that is, literature that was published to be smuggled into Russia. The remainder was printed in Russia in the brief period following the revolution of 1905 . The chief importance of these writings is that in them can be found the ideas that in time helped to bring about the downfall of the monarchy. Bolsheviks, Mensheviks, anarchists, constitutional reformers, agricultural reformers-all the competing groups - are represented.

(Continued on page 152) 
London, E.C. 4. v.1, no.1, July 1956. Frequency not given. $£^{3} 10 \mathrm{~s}$.

Polish Medical History and Science Bulletin. Polish Medical Alliance, 2424 N. Kedzie Blvd., Chicago 47. v.l, no.1, July 1956. Frequency not given. $\$ 1.50$ per issue.

Portugal. Secretariado Nacional da Informacão, Lisbon. no.1, July/August 1956. Frequency not given. Price not given.

Quadrum. Association pour la diffusion artistique et culturelle, Palais des beaux-arts, 10 Rue Royale, Bruxelles. no.1, May 1956. Semiannual. Price not given.

Review of Eastern Medical Sciences. H. G. Schulz, Postfach 26, München 62. no.1, January/March 1956. Frequency not given. Free. Revista de Administración Pública. Instituto de Administración Pública, Av. Juárez 4-807, Mex- ico 1. no.1, January/March 1956. Frequency not given. Price not given.

Revista de Ciencias Juridico-Sociales. Universidad de Costa Rica, Apartado 3862, San José. v.1, No.1, March 1956. Frequency not given. Price not given.

Revista Universitaria. San Martín 244, Buenos Aires. v.1, no.1, May 1956. Frequency not given. $\$ 30$ for 6 no.

School Planning. 75 E. Wacker Drive, Chicago 1. v.1, no.1, June/July 1956 . Bimonthly. $\$ 5$.

Scripta Manent. Holbeinstrasse 57, Basel. v.l, no.1, September 1956. Semiannual. Fr S 20.

Studi Internazionali di Scienze e Lettere. Instituzione Roerich, Via Rizzoli 4, Bologna. v.l, no.1, March 1956. Quarterly. Price not given. Zeitschrift für Slawistik. Akademie Verlag, Berlin. v.1, no.1, 1956. Quarterly. DM 12 per issue.

\title{
Sources for the Study of European Labor and Socialism (1840-1914) at Wisconsin
}

\author{
(Continued from page 143)
}

The periodicals are easily the prize of the Russian collection, if for no other reason than that to acquire them now on a piece-by-piece basis would be a hopeless task. Each one is a rare item. The most famous of them all, but not the rarest, is Iskra, of which Wisconsin has all 112 issues. Lenin was among those who founded this organ of the Social Democratic Party. Later, when Lenin went into the opposition, he founded the Vpered. The Osvobozhdenie, of which 79 issues appeared, represented the non-revolutionary constitutional reformers. Finally, and the temptation to list more is strong, there is the Svobodnoe Slovo, issued by the followers of Tolstoi.

\section{The "International"}

As an agency within which the socialists revealed their differences in outlook, and as a platform for propagandistic ac- tivity by Marx, the International Workingmen's Association (founded 1864) is worthy of study. Of the proceedings of this Association, Wisconsin has an almost complete file; unfortunately, there is lacking the parallel material for the anarchists, bitter enemies of Marx.

The outstanding item on the International is the manuscript book of the minutes of the meeting of 1872 , the year in which the anarchists were expelled from the Association. This minute book, never before published, will soon appear in printed form.

In the proceedings of the Second International (founded 1889) can be traced the warfare between the various socialist groups and the attempts of the participants to settle the differences between the Russian representatives. Wisconsin has a complete file of these proceedings. 